\title{
The Qur'an and Identity in Contemporary Chinese Fiction
}

\author{
Wen-chin Ouyang \\ SOAS, UNIVERSITY OF LONDON \\ 你們一齊抓住真主的繩索 \\ Hold fast to God's rope all together
}

(Q. 3:103)

\section{The Qur'an in China}

I begin my exploration of the relationship between the Qur'an and identity in contemporary Chinese fiction with this quotation from the Qur'an because it encapsulates the communitarian impulse underpinning the writings of the two Chinese Muslims I have chosen to look at: Zhang Chengzhi (張承志, b. 1948) and Huo Da (霍達, b. 1945). It informs their identity politics. The verse itself appears in Zhang's novel, A History of the Soul, Xing-ling-shi (心靈史, 1991), ${ }^{1}$ and, to the best of my knowledge, it may be the only quotation from the Qur'an found in the works of fiction written by Chinese Muslims. There are no quotations from the Qur'an in Huo Da's A Muslim Funeral or Muslim Funeral Rites (Mu-si-lin-de-zang-li, 穆斯林的葬禮, written in 1982 and published in 1988). Zhang and Huo are Muslims who have achieved both fame and critical acclaim in China as writers of fiction, albeit in very different ways. The two novels I examine here are unique even among the works of Zhang and Huo, for they represent a departure in their respective literary careers. These works unmask the 'ethnic origins' of the two writers, and in Zhang's case, A History of the Soul marks his rebirth as a Muslim, birth as an activist in the Muslim community in China, and transformation as an author. ${ }^{2}$ The absence of the Qur'an, the first and foremost sacred and paradigmatic text in Islam, from two of the most important literary works by Chinese Muslims, who assert through them their Muslim identity in today's unabashedly multicultural China, challenges perceptions about Muslims and their relationship with their sacred text. 
The Qur'an has been taught to generations of Chinese Muslims since the eighth century in mosques, madrasas, and possibly homes, wherever Muslims have migrated across what is known as China today. Even though it was partially translated into Chinese first in 1862 in Yunnan, ${ }^{3}$ Chinese Muslims have to, and do, learn the Qur'an in a rudimentary fashion that only allows them to say their five daily prayers properly. Arabic education has tended to be reserved for those who are being trained for religious vocation, mullahs, at least until after 1991 and 1992, when summer classes for children were introduced. It also focuses on 'memorizing the sounds of Qur' anic recitation', ${ }^{4}$ according to Maris Boyd Gillette in her study of Muslims living in Beijing. However, there is disagreement about how best to learn the sound of the Qur'an. Some advocate teaching the Qur'an in Arabic and others insist on using transliteration in Chinese characters that can only approximate the sounds of Arabic. ${ }^{5}$ Access to Arab and Muslim scholars from the Arab world and the Middle East fluctuates considerably, and is dependent in the main on 'government' policies. The relatively reticent foreign policy of the Song (960-1279) and Ming (1368-1644) dynasties and China in the throes of the Cultural Revolution (1966-76) meant that Chinese Muslims lived in isolation from the broader Muslim Community, while the openness of the Tang (618-907), Yuan (1271-1368), and Qing (1644-1912) dynasties, as well as post-Mao China, saw heavy traffic between Chinese Muslims and the Muslims in the Middle East, as evidenced by the most recent wave of what scholars of Islam in China call 'modernisation and Arabisation', or the ways in which Muslims in China aspire to live a lifestyle on a par with that of the Muslims in the Arab world, ${ }^{6}$ including literacy in Arabic.

'Government' policies have also affected the patterns of Muslim migration and settlement in China across time, space, and ethnicity. While the Tang and Song dynasties, for example, confined the presence of Muslims, mainly of Arab and Persian descent, as well as other 'outsiders', in commercial centres along the Silk Road or on the coasts of Indian and Pacific oceans where traders from all over the world congregated, the Yuan dynasty deployed Muslims as mercenaries in the army and brought masses of Central Asian Muslims into the heartland of China, and the Ming dynasty encouraged Muslims to join the government bureaucracy. The history, geographical spread, and ethnic make-up of Muslim Chinese today are as complex as those of the Middle East. Known as Hui in Chinese, they in fact belong to ten ethnic groups: Uyghur, Kazakh, Dongxiang, Kirghiz, Salar, Tajik, Uzbek, Baoan, Tartar, and those of Arab and Persian descent. They live practically everywhere and partake fully in the cultural and commercial life of China. The largest group of Chinese Muslims, who are also differentiated from other ethnic groups today by the designation 'Hui', are most likely the descendants of Arab and Persian traders who, unlike the Turkish speaking Central Asian nomadic groups, have become so integrated into the Chinese population through marriage and adoption of local languages and lifestyles that they 
cannot be distinguished even physically from the Han, the assumed 'ethnic' majority in China who have dominated the cultural landscape in East Asia for more than two thousand years. In the long history of Hui in China, which is as long as the history of Islam, Chinese Muslims have insisted on observing Islamic edicts. Three features associated with their religious observance have become their identity markers: observation of religious rituals, Huihui speak, and habits of food consumption. Muslims in China, like Muslims around the world, perform individual or group prayers, fast during the month of Ramaḍān, go on pilgrimage to Medina and Mecca, and observe Muslim rites during birth, circumcision, marriage, and burial. They pepper the local Chinese language they have adopted with Arabic and Persian terms denoting religious rituals and edicts that are visible only to insiders to the Muslim community. They adhere to 'clean' or 'pure' eating (qing-zhen, 清真) that is free of pork and alcohol, to ritual slaughtering of animals, and to specific ways of preparing food. Their cuisine, especially noodles, bread, and lamb, have become staple features of Muslim cuisine, which outsiders to the Muslim community seek and enjoy, whether in areas inhabited by Muslims or restaurants run by Muslims in any Chinese metropolis. ${ }^{7}$

\section{Zhang Chengzhi and Huo Da as Minority Writers}

Zhang and Huo belong to this Hui majority group (among the ten Muslim 'ethnicities' or 'nationalities') ${ }^{8}$. Both were born in Beijing and went through a secular Chinese education during the height of the Cultural Revolution. Zhang was raised as an atheist and was an active 'red guard' during his high school days. He obtained a bachelor's degree in archaeology at Beijing University in 1975, and a master's degree in history at the Chinese Academy of Social Sciences in 1981. He is fluent in Mandarin and Mongolian, speaks Japanese, and knows some Arabic, Kazakh, and Persian. He began his writing career in 1978, with the publication of a poem in Mongolian entitled 'Son of the People' (Arad-un-huu, 做人民之子) and a Chinese-language short story, 'Why does the Rider Sing?' (Qi-sho-wei-she-me-ge-chang, 騎手為什麼歌唱). $\mathrm{He}$ is now best known for his novels, which were published between 1981 and 1991. A History of the Soul seems to have been his last novel. He has since become an advocate for Islam in China and an activist within the Chinese Muslim community, calling for educational reform in mosques and madrasas. Huo, whose Muslim name is Fatima, comes from a famous family of jade craftsmen. She studied engineering at school, but preferred literature and history, and eventually made her career as a writer of historical dramas for television and cinema. She is also renowned as a fiction writer, most famous for her novel A Muslim Funeral, which won the 1991 Mao Dun Literature Prize (Ma-dun-wen-xue-jiang, 茅盾文學獎). ${ }^{9}$ In her foreword to A Muslim Funeral, Bingxin (冰心, 1900-99), one of the most important and prolific Chinese writers of the twentieth century, praised the unique literary 
accomplishments of the work, and expressed her surprise at finding out that Huo was a Muslim.

A History of the Soul and A Muslim Funeral have in common the 'coming out' of their authors as 'ethnic' or 'minority' writers. Their 'coming out' is possibly traceable to the context of the broader literary and cultural 'root-seeking movement' (xun-gen, 尋根), that began in China in the late 1980s, coinciding with the so-called 'postrevolutionary' period under the leadership of Deng Xiaoping (1904-97) from 1979 to 1997. ${ }^{10}$ Its premise is that the Cultural Revolution destroyed a pluralistic Chinese identity that had existed for centuries, and that the reconstruction of that identity requires a healthy appreciation of local and minority cultures. These two novels are similarly preoccupied with tracing the history of Muslims in China, mapping the trajectories of their integration, or lack thereof, into Chinese culture and society, and tracking their distinct identity markers. The similarities between the two authors stop here. Their styles and politics cannot be more different. Zhang's dissonant, loud, and assertive communal rhetoric may be contrasted to Huo's melodic and self-questioning domestic melodrama. The 'fundamentalism' of A History of the Soul is also diametrically opposed to the self-questioning existential anxiety lurking beneath the surface of A Muslim Funeral. Zhang's 'born-again Muslim' persona will not find sympathy with Huo's more secularist impulses. Despite their divergent political agendas and narrative strategies, however, both would insist that it is possible to be both Chinese and Hui at the same time. There is no contradiction between the two, for being Chinese is an encompassing cultural framework into which ethnicity may be subsumed, and here 'Chinese' is no longer synonymous with Han, the 'ethnic' majority, but denotes the culture in the production of which all the 56 ethnic groups of China participated. The problem lies rather in the 'language' through which Chinese culture is expressed, Chinese history narrated, and Chinese literature written and appreciated, which has thus far been Han-centric, and has suppressed the contributions of the 55 non-Han 'ethnicities'. Both Zhang and Huo unsurprisingly adopt the two narrative strategies Deleuze and Guattari highlight in Kafka's writings, or the strategies he deploys to overcome his minority status in a major literature (as a Czech Jew writing in German): deterritorialisation and reterritorialisation. ${ }^{11}$ Just as Kafka defamiliarised the German language in his novels and injected into the German literary landscape an outsider's imagination and sensibility, Zhang and Huo create in their novels, out of the same overlapping narrative processes, a literary world that is at once common to all Chinese and unique to the Muslim Chinese.

\section{Deterritorialisation of the Sinophone}

Mandarin has been the dominant, or even the canonical, Chinese language since the eighteenth century. This northern dialect, native to Beijing, was declared the official language of the Republic of China in 1911 and the People's Republic of China in 
1949. This Chinese language is underpinned by a system of writing, what I would call Sinophone, based on a semiology dominated by a tradition of use and the Confucian worldview, but is at the same time open to regional inflections of local Chinese languages, and perhaps even other worldviews and 'foreign' cultures. Written Chinese may have picked up in the three-thousand-year history of its development, let us say, Buddhism and Daoism, but it is today associated with Han-centrism that has canonised genres of writing, bodies of texts, and groups of authors, privileging a set of politics, ethics, and aesthetics from which the Hui language and worldview, among others, are allegedly excluded. I say 'allegedly' because it is not entirely clear yet whether the Hui were indeed absent from Chinese culture and literature, for there is a substantial body of writing in Chinese by Hui authors that has yet to be studied, analysed, and made relevant to the Sinophone. What is already known, albeit in rather abstract and general terms, is that Chinese Muslims indeed made contributions to Chinese astronomy, medicine, literature, and painting, and that they also translated key Șūfī texts into Chinese using Confucian concepts and language. ${ }^{12}$ However, from the contemporary perspective, or that of today's Mandarin, there is a kind of cultural amnesia that has rendered the Hui invisible. Both Zhang and Huo take advantage of this possibly temporary cultural amnesia and remap the Sinophone by inserting into it the language of the Hui.

Both texts are peppered with 'Huihui speak' (回回話). ${ }^{13}$ A History of the Soul, a reconstruction of the history of the Șüfî Jahriyya sect in the eighteenth and nineteenth centuries in the form of a journey of spiritual self-discovery, deploys Șūfī terms in Arabic and Persian throughout the narrative. References to recitations of Qur'anic suras (suo-le, 索勒) exist side-by-side with the Prophetic Tradition (sunna; sun-nai-ti, 简乃提), Muslim purification practices ( $g h u s l ; w u$-si-li, 烏斯里, and ābadast; $a$-budai-si, 阿布黛斯), Islamic notions of this world (dunya $;$; dun-ya, 頓亞), and the Paradise of the hereafter, the Garden of Eden (zhen-jing-hua-yuan, 真境花園), and martyrdom (shahāda), or martyrs (shuhada ${ }^{\jmath}$; su-hai-da-yi, 束海達依), and the beauty of the martyr (sūrat; su-lai-ti, 蘇萊提); Șūfī notions of miracles (karāma, ke-la-mai-ti, 克拉麥提), saints (walī; wo-li, 臥裡), the shaykh (sha-he, 沙赫) and the mawla (mao-la, 毛拉); the Șūfî organisational structure, including leaders (murshid; mu-le-she-de, 穆勒什德), preachers ( $d \bar{a}^{c} \bar{l}$; da-yi-er, 打依爾), and disciples (mulla; man-la, 滿拉); and Șūfî ritual practices of recitation (dhikr; ji-ke-er, 即克爾), circumambulation (d $\bar{a}^{\jmath} i r a ; d a-y i-e r$, 打依爾), prayer $\left(d u^{c} \bar{a}^{\jmath} ; d u-a-e r\right.$, 都阿爾), and visitation of saints' tombs (qubba; gong-bei, 拱北); along with Șūfī genres of writing (mukhammas; mu-han-mai-si, 穆罕麥斯, and 'rashshah'; re-she-ha-er, 熱什哈爾, and manāqib; man-na-gei-bu, 曼納給布).

These terms appear as a seamless part of the textual composition, at least to readers familiar with Islam and the Arabic and Persian languages. They are always accompanied by explanations in the text or in the footnotes. They have an initial 
jarring effect on the readers of the contemporary 'colloquialised' Chinese literary language, bai-hua (白話), but are meant to be integral parts of a first-person narrative that details the journey of spiritual self-discovery. This journey of spiritual awakening unfolds in the footsteps of a nameless protagonist, who goes on a pilgrimage to the tombs of the Jahriyya 'martyrs' across China, from the northwest, where the Jahriyya sect was established, to the south, then northeast, where the Jahriyya followers fled or were exiled, then back to the northwest. ${ }^{14}$ As the protagonist stops at each tomb and pays homage to the 'martyr' it enshrines, he recounts their life story (biography), here, which in turn reconstructs from secret Arabic and Persian texts that extol the martyrsaint's miracles, virtues, and devout practices, and that express the Șūfî passion for God, desire for union with Him, and disdain for this life (or yearning for martyrdom). The poverty of the Jahriyya adherents and their disregard for their life, their loyalty to their faith, sect, and leaders, and their 'endurance' in the face of persistent persecution and massacre, inspire awe and wonder. How is it that those who have nothing are able to die for a cause that gives them nothing in return? It is spirituality, not religion (zongjiao, 宗教), that ought to inform idealism (li-xiang, 理想), aspiration (xi-wang, 希望), and humanism (ren-dao, 人道), ${ }^{15}$ the kind of spirituality of which Confucianism is devoid. ${ }^{16}$

Zhang is careful to set the site of his novel on the barren lands of the Loess Plateau in northwest China (huang-tu-gao-yuan, 黃土高原), and more particularly in the Jahriyya's main residential site, Xihaigu (西海固). Xihaigu is the acronym for the tri-country area of Xiji (西吉), Haiyaun (海原), and Guyuan (固原) in the present-day south Ningxia (寧夏) Hui autonomous region. The barrenness of the Loess Plateau that inspired passionate Șūfĩ devotion is contrasted to the fecund heartlands of China that produced the barren spiritual landscape of Confucian Chinese culture. It is on this barren landscape, where Confucian influence, tong-zhi-zhong-guo-de-kong-meng-zhi$d a o$ (統治中國的孔孟之道), is at its weakest, that the protagonist's brand of religious fervour, zealous idealism, and universal humanism is born, in Zhang's account, against the background of the two-hundred-year history of the Jahriyya's passionate engagement with Șūfism and consequent martyrdom. ${ }^{17}$ This newly-born worldview goes against the grain less of the historical Confucianism but more of the contemporary neo-Confucianism which has been instrumental in legitimating the reintroduction of a peculiarly Chinese communist sort of capitalism, or liberalisation, in Deng's China. However, all did not have equal access to the fruits of liberalisation, or of 'the end of Cultural Revolution and opening to the West', as Morris Rossabi observes: ${ }^{18}$

Nearly all of the initial efforts of the government, international aid agencies, and foreign investors were directed at the coastal regions of China. For almost two decades, the minority regions lagged behind. In the mid-1990s, however, the government turned its attention to the 
interior, or western, parts of the country - the homelands of the more populous minority groups. It promised greater domestic and foreign investment for these economically deprived areas. Though it is too early to assess the success of this policy, preliminary patterns point to favoritism toward the new Han settlers in the minority regions.

Another polarisation expectedly underlies the highly problematic juxtaposition between the materialism of Confucianism and the spirituality of Șūism. The oppressed 'people' (ren-min, 人民) is set against the tyrannical 'government' or 'state' (guo-jia, 國家). The novel is both about Hui and Han conflicts - the protagonist is utterly shocked and distressed when 'he' finds out that the Jahriyya followers were capable of massacring ( $t u$-sha, 屠殺) Han people-and the irreconcilable differences between spirituality and materialism. This is staged in the form of positional differences between the 'state', or political authority, here represented by the Qing general Tso Tsung-t'ang (Zuo Zongtang, 左宗堂), ${ }^{19}$ and the 'masses', here necessarily the have-not peasants, as Zhang describes the Jahriyya adherents. The state, even a communist one, will inevitably oppress the masses, and there can be no clear line of escape from this kind of Hegelian 'master' and 'slave' dialectic. It is also symbolic of the materialism of Confucianism, or the priority it gives to joining and climbing the government bureaucratic ladder, for membership in the state is the ultimate means to wealth and, therefore, success. It is precisely because the Hui, according to Zhang, never assumed political power at any time in China, unlike the Han and other ethnicities such as the Mongols and the Manchurians, that they can more effectively, and poetically, serve as the symbol of the underprivileged and oppressed peasant masses. The semantic shift in his transliteration of the term 'Jahriyya' in Chinese is significant. Zhang deviates from the common transliteration of Jahriyya into the following characters of 哲赫仁耶 (zhe-he-ren-ye), 哲军仁耶 (zhe-han-ren-ye), or 哲赫林耶 (zhe-he-lin-ye), and renders it instead as 哲合忍耶 (zhe-he-ren-ye). He changes the second character, 赫 or 肎, which approximate the sound of the Arabic $h \bar{a}^{\jmath}$ in the word jahriyya and denote 'red' and 'rare' respectively, to 合, which now means 'unity' or 'union', and transforms the third, 仁 or 林, which approximate the sound of Arabic $r \bar{a}^{\supset}$ and mean 'mercy' or 'forest' in Chinese, to 忍, or 'patience' or 'endurance'. The story he tells in A History of the Soul is that of 'peasant' endurance and of survival under 'government' tyranny by virtue of the strength of faith and community bond, and of spirituality's triumph over materialism.

There are conceptual and other problems attendant in Zhang's double polarisation, between Confucian materialism and Șūfī spirituality, and between the 'state' tyranny of Qing and 'mass' victimisation of Hui, as will be seen later, but for now the introduction of 'Huihui speak' in A History of the Soul initiates a radical reformulation of the contemporary Chinese novel. Transliterated Arabic and Persian terms open up the text of the novel to a floodgate of Suufì influences. The novel is divided into seven 
sections - and seven is the perfect number in Șūfī writings - each called 'gate' or 'door' (men, 門), imitating the ways in which sections in Arabic or Persian works are designated $b \bar{a} b$, and evoking at the same time the organisation of Șūfì orders into tarīqas (men-huan, 門宦 in Chinese). Each section is a 'biography' of one of the murshids, leaders, of the Jahriyya sect, written not as a familiar Chinese biography, zhuan-ji (傳記), but as Arabic or Persian Șūfĩ manāqib ('virtues [of a saint]'). The stories of miracles and devotion add substance, and explications of Șūfī spirituality (rashshah) and devout expressions (mukhammas) contribute passion and lyricism.

A Muslim Funeral is a more subtle discourse on identity; it is equally interested in restoring the Hui presence in Chinese culture and literature but is less radical in its political discourse. It narrows the focus to the family of a jade craftsman, Liang Yiqing (梁亦清), who in spite of his fame lives a modest life in Beijing in the twentieth century up to the end of the Cultural Revolution. When an itinerant shaykh finds his way to the Liang house, thanks to a secret marking known only to Muslims that identifies it as Muslim household, and invites wayfaring Muslims to seek shelter within it, the four-character inscription jing-zi-du-a (經子堵阿), this family melodrama unfolds. It is the story of a Muslim community trying to hang on to its identity in the turbulent republican era, starting in 1919, going through the two world wars, the communist takeover of China and the Cultural Revolution, and ending in 1979. Even though 'Huihui speak' is spoken only within the community, the Muslim Quarter in Beijing with Ox Street (牛街) as its main street, here designated as dār al-Islām (da-er yi-si-lan, 達爾。伊斯蘭), ${ }^{20}$ it is an identity marker, as Mandarin is now in the greater Sinophone world (including overseas Chinese communities). Muslim greetings, 'Peace be upon you', or al-salām 'alaykum (an-sai-lia-mu-er-laikun, 按賽倆目而來坤) and the response wa- ${ }^{c}$ alaykum al-salām (wu-er-lai-kun-mensai-lia-mu, 吾而來坤悶賽倆目), ${ }^{21}$ eating habits and cuisine, prayers and devotional practices, and marriage and funeral rites are carefully explained and distinguished from those of other 'ethnic' groups, especially the majority Han. The arrival of the itinerant pilgrim by the name of Tu-luo-ye-ding (吐羅耶定), an ordinary Muslim not a religious leader (shaykh; shi-hai, 篩海), and his disciple, Ibrāhīm (yi-bu-la-xin, 易卜拉欣), who are on their way to Mecca to visit the Ka'ba (ke-er-bai, 克爾白) and kiss al-hajar al-aswad, the black rock known as the [right] hand of God (tiansho, 天 手), calls for hospitality. Such an occasion also serves as an opportunity for an explanation of Muslim practices. Ghusl, known as the 'big cleansing' (da-jing, 大淨), is not possible during long-distance travel, and the old pilgrim and his disciple have been substituting water with sand (dai-jing, 代淨, or tayammum in Arabic), until their arrival at the Liang residence. The cleansing rite is followed by a group prayer led by the itinerant pilgrim and joined by the host family, which occasions the enumeration of five daily prayers: morning (Bāmdād; ban-da, 榜答); noon (Pīshīn; pie-shi-ni, 政什尼); afternoon (Dīgar; di-gai, 低蓋爾); evening (Shām; 
sha-mu, 沙目); and night (Khuftan; hu-fu-tan, 虎伏灘). ${ }^{22}$ Key to the novel, however, are the two weddings and the funerals that serve as the catalyst for distinguishing the Liangs as a Muslim family.

The death of Liang Yiqing, the patriarch of the family in Part I, brings the Muslim community together for his funeral rites. His body is placed with the head towards the north, face west towards Mecca, and legs towards the south, on a mat especially prepared for the occasion (shui-liu-zi, 水溜子, or han-tuo, 旱托), then cleansed (ghusl; wu-si-li, 務斯里), and wrapped in a white shroud (bai-man, 白幔, clearly a translation of the Arabic kafan). The dead must be buried within three days, and on the third day, the Muslim religious leader, ākhūnd (阿訇), heads a procession made up of members of the community, who take the body to a grave (la-he, 拉赫), dug to specific instructions (first south to north, then east to west), then bury him in the midst of recitation of the Qur'an and prayers. The funeral is followed by a meal provided by the family and to which members of the Muslim community bring nietie (七帖). This is the one third of the property of the deceased in a Muslim family that is allocated for giving away to other bereaved Muslim families during the funeral rites as part of seeking forgiveness for the deceased (isqāt; yi-si-ka-tuo, 以思卡脫). ${ }^{23}$

The communal orientation and simplicity that mark a Muslim funeral also distinguish a Muslim wedding from those of the Han. Ibrahim, now given a Han name, Han Ziqi (韓子奇), after he decides to stay with the Liang and learn his craft upon breaking one of Liang's jade pieces, marries Liang Biyu (梁壁玉) at a simple ceremony at the mosque after the Friday congressional prayer (juти ca; zhu-ma, 主麻). The ākhūnd serves as the wakīl (gu-wa-xi, 古瓦西), translated into Chinese as 'matchmaker', and in attendance are the members of the Muslim community (dustān; $d u$-si-ti, 杂斯提). The $\bar{a} k h \bar{u} n d$ writes the marriage certificate ( $\bar{l} j a \bar{a} b ; y i-z h a-b u$, 意札布) after the exchange of vows, she saying, 'I give permission (dadān; dan-da, 且達)', and he saying, 'I accept (qabiltu; gai-bi-erh-tu, 蓋畢爾圖)', and this is followed by congratulations from the congregation (ubārik or mubārak in Persian, wu-ba-li-ke, 唔 吧哩克). ${ }^{24}$ The description of this simple ceremony is preceded by a very elaborate explication of the Chinese Muslim marriage rites. Marriage among Chinese Muslims is a duty ( $w a \bar{a} i b$; wa-zhi-bu, 瓦直卜) and a community affair. Parents, through a professional matchmaker, begin negotiations until an agreement is reached for their children to be married. A small engagement (xia-ding, 小訂), in which the future bride and groom exchange token gifts and the fathers shake hands (na-sho, 拿手), precedes a formal engagement (da-ding, 大訂) when larger gifts are exchanged and a wedding date set. On the wedding day, Muslims celebrate as the Han do, except for the content of the banquet, at which Hui food would be served, and the marriage rites performed. An $\bar{a} k h \bar{u} n d$ presides over the wedding ceremony, writing the $\bar{l} j \bar{a} b$ and witnessing the exchange of vows between bride and groom. 
Such painstaking detailing of wedding and funeral rites, punctuated by 'Huihui speak' and careful discussions of the overlaps and divergences between Hui and Han rites, strategically inserts the history of Hui in China into the general history of China, and marks the Muslim community as separate from the Han. If Han Ziqi and Liang Junbi's (梁君壁) wedding is simple, their son's marriage to his sister's best friend is an elaborate affair, not only as a public spectacle but also as an assertion of a Muslim tradition, that of never marrying an outsider, a non-Muslim, into their community. Han Tianxing (韓天星) is in love with a Han woman, Rong Guifang (容桂芳), a colleague at the factory where he works in Mao's China, but his mother manipulates the situation to lead Rong to misunderstand that Han is already betrothed, and then practically forces her son to marry a Muslim girl, Chen Shuyen (陳淑彥), his sister's best friend. The mother, Liang Biyu, is asserting her authority both as mother and keeper of tradition. Marriage is not a matter for the individuals concerned but for the entire community, who must follow their tradition fully in order to survive as a distinct group. The threat of the Chinese dār al-Islām being absorbed into Han is so great that even men are no longer allowed to marry non-Muslims. She is understandably also against her daughter's love interest, Chu Yanchao (楚雁潮), her English teacher at Beijing University. Another form of tragedy, Liang Xinyue's (梁新月) premature death at twenty, prevents her from a fate similar to her brother's.

These two weddings and two funerals - and I will come to Han Ziqi's funeral in a moment - are the nexus of two intertwined narratives in Huo's melodrama, one on the loves and tragedies of Han Ziqi, Liang Junbi and her younger sister, Liang Bingyu (梁冰玉) between the two world wars, and the other of the loves and tragedies of their children Han Tianxing and Han Xinyue in Mao's China before, during and after the Cultural Revolution. The two major narratives are divided into alternating chapters, one from each timeframe, until the story comes to a head and all mysteries are revealed and explained. Each narrative is identifiable by the designation given to its constituent chapters. The story of the parents are told in chapters given titles structured around 'jade' ( $y u$, 玉), and that of the children in those around 'moon' (yue, 月). On one level, the novel is made up of the stories of the two sisters who have variants of jade in their names, $b i$ (壁) and $y u$ (玉), and of a brother and a sister who have star and moon in their names, xing (星) and yue (月). On another level, it is the story of two generations' relationship with the Han, through the supply and demand of the jade trade and craftsmanship between the two world wars, and of two star-crossed love affairs in communist China, when religion was banned and jade craft and trade were nationalised. Unlike Zhang, Huo does not polarise between 'state' and 'people'. Her polarisation between the Hui and the Han, like Zhang's, is ambivalent, but her discourse on the Han is even more subversive. If Zhang exposes a history of antagonism between the Hui and the Han, Huo tells a story of the relentless exploitation of the Hui by the Han. 
Zhang's clamorous 'historical romance', if one may thus describe A History of the Soul, and Huo's unobtrusive melodrama, if such terms may be applied to A Muslim Funeral, incorporate different sets of the vocabulary of 'Huihui speak' to inscribe the presence of Hui not only in their texts but also in the Sinophone cultural and literary landscapes. The different vocabulary selected for rhetorical deployment is determined by the subject matter and, above all, focalisation. Zhang's engagement with the imperial history of the Qing Dynasty through the prism of the 'secret history' of a Șüi sect, and with the 'spiritual emptiness' of Confucianism, has steered his diction in the direction of faith and his narrative composition to the devotional genres in Arabic and Persian. His strategically politicised choices, all in transliteration, are enabled by his familiarity with, even if only smatterings, of Arabic and Persian and Șūfĩ genres of devotional expression in those languages thanks to his rebirth as a Muslim and his turn to the 'religious elite' to study Islam as a believer. Huo's narrative is centered on the domestic sphere, on the stories of two generations of star-crossed lovers, that opens out centripetally to broader communal and national issues, to the ways in which the Chinese Muslim community negotiates its place in China and its social and cultural integration into and separation from the larger Chinese society and culture. Her Huihui vocabulary, a combination of transliteration and translation, and the structure of her novel, unaware of Arabic or Persian writing as compared with Zhang, reflect her concern with immediate social issues and distance from Arabic and Persian. The recurrence of $d \bar{u} s t$ or dūstān (duo-si-ti, 杂斯提), defined by Zhang as 'brother', 'friend', and 'fellow faithful', in both texts, however, signals their shared belief in the tacitly acknowledged but unquestionably unbreakable bond among Chinese Muslims, and belief that the fate of their community is separate but inseparable from the history of China. The history of the Hui is a part of the history of China and it must be restored to its proper place in Chinese historiography.

\section{Reterritorialisation of Chinese History and Story}

Zhang chooses the Jahriyya as the locus of his interrogation of Chinese historiography. A History of the Soul rewrites the history of this Șüfi sect, which is one among more than 40 in China, from the perspective of the victim, the Jahriyya, who suffered attempts at annihilation in the latter part of the Qing rule of China during the eighteenth and nineteenth centuries. Zhang's interest in Chinese Muslims, particularly the Jahriyya, began earlier, as Howard Y.F. Choy shows, and took the form of a 1989 novella, 'Investigation of Assassination in the Western Province' (Xisheng ansha kao, 西省暗殺考), which focuses on a single historical event, an assassination attempts made on the life of a Qing general, Liu Jintang (劉錦堂, 1844-94), who executed Ma Hualong (馬化龍, 1810-71), even though the latter had already surrendered to Liu in a gesture of compromise, sacrificing himself in order to save his family and community. The failure of revenge in this story, Choy argues, is 
not simply about the futility of revenge, as Zhang's secular critics would see, but about the ways in which social injustice drives a 'people' to faith, to believe in God and in the leaders He has chosen for them, and about how violence (or vengeance) may be transformed into nonviolence (through female blood). ${ }^{25}$ A History of the Soul is a sequel, so to speak, but, rather than one event, it now covers the entire twohundred-year history of the Jahriyya, from the reign of Qianlong (乾隆) (r. 1736-95) to the overthrow of the Qing Dynasty in 1911 and the early republican era. It is seen from a completely inside perspective, effected through a positional reversal that ascribes victory, here necessarily a moral one, to the victims, the Jahriyya sect, and defeat to the victimisers, the Qing governor-general of Shaanxi and Gansu, Zuo Zontang (左宗堂, 1821-85), and his generals, who were based in Lanzhou (蘭州).

Qing historical records are 'written over'; they serve only as the blueprint for a complete rewritten history of the Jahriyya, a microcosm of Hui, made up of Arabic and Persian works. These include a rashshah, an Arabic story of the life of the Jahriyya founder Ma Mingxin (馬明心, 1718-81) and a Persian account of the deeds of Mu Xianzhang (穆憲章, d. 1812), manāqib attributed to Zhanye (亶毛爺), the Arabic chronicle 'A Tale of Lanzhou' (Lanzhou Zhuan, 蘭州傳), and al-Kitab al-Jahrī by the imām Mansūr (曼蘇爾), aka Ma Xuezhi (馬學智), superimposed on Qing historical records. ${ }^{26}$ The history of the Jahriyya is, like that of Diaspora Jews, a series of victimisations and forced migrations. Zhang's history of Jahriyya is, of course, ahistorical. His demonisation of Zuo Zontang and deification of the Jahriyya sect flatten the turbulent history of China in the two centuries preceding the overthrow of the Qing Dynasty, during which the Manchu ruled, and the beginning of the republican era, when the Han resumed political control over China. It conveniently overlooks the Jahriyya involvement in conflicts with other Islamic sects and their Han neighbours, during which all parties engaged in mutual massacring and looting. It also overlooks their possible alliance with 'insurrections' led by the Han and other ethnic groups, including the Dongxiang and Salar Muslims, who resented equally their Manchu overlords. The Hui were even accused of colluding with the Taiping rebellion (1853-64), a Christian insurrection led by Hong Xiuquan (洪秀全) and based first in Guangxi, then Nanjing, that called itself the Heavenly Kingdom of Great Peace (Taiping Tianguo, 太平天國), which was considered a major threat to the Qing dynasty.

The Jahriyya Hui, like other Chinese Muslims, were not all innocent passive bystanders. Some were drafted into the Qing army and deployed to help suppress the Taiping insurrection around 1862. Others organised themselves into armed forces and rebelled against Qing rule. These forces were comprised of peasants but also of artisans, small traders, peddlers, labourers, and even religious leaders. The founder of the Jahriyya, Ma Mingxin (馬明心), may have insisted on refusing community donations and disengaging from politics, but his practices did not last long. Ma Hualong (馬化龍), the leader of the Jinjibao (金積堡) rebellion, was himself a 
rich merchant and warlord. This is not to say that Zuo Zongtang did not massacre the Jinjibao Hui after their surrender or use brutal force to suppress Hui and other 'insurrections', 27 as Zhang asserts, but that Zhang in his romanticising of the Jahriyya Hui as spiritually enlightened peasants passively receiving brutal treatment and enduring it, goes overboard in demonising Han officers of the Qing Dynasty. His insistence on drawing a parallel between the Jewish Diaspora and Jahriyya dispersal is problematic too. Perhaps there is some surface resemblance between the Jahriyya's forced migration in China and out of China, especially in the nineteenth century, and the wandering of stateless Jews around the world until the founding of the State of Israel in 1949, but the voluntary Arab and Persian migration to China is not really comparable to the Jewish Diaspora, nor the massacre of the Jahriyya to the Holocaust.

Two paradoxical impulses drive Zhang's narrative. One is to destabilise Qing historical records as well as classic Chinese fiction and create a dissonant and alienating effect in Chinese historiography and the Chinese novel by superimposing on them the history of Jahriyya and the various genres of Arabic and Șūfĩ devotional expressions. The second is a concomitant contradictory desire to situate his novel within the tradition of classic Chinese novels, especially the historical romance. The title of the fourth chapter in the last and seventh part of A History of the Soul is the (first) sentence with which The Romance of the Three Kingdoms begins: 'The empire, long divided, must unite; long united, must divide' (tian-xia-da-shi, fen-jiu-bi-he, he-jiu-bi-fen, 天下大勢, 分久必合, 合久必分'). ${ }^{28}$ Zhang re-orders the sequence of this trajectory of an empire's life to 'the empire, long united, must divide; long divided, must unite' (he-jiu-bi-fen, fen-jiu-bi-he, 合久必分, 分久必合'), as if he were willing the Chinese Muslim community to unite. A History of the Soul is a meeting place of Hui history and Chinese historical romance. It is not The Romance of the Three Kingdoms, far from it, but it aspires to be considered a Chinese historical novel with a difference. It does have an epical sweep. It covers the vicissitudes of a community over a period of 200 years, detailing the defeats and dispersals of this community until the nationalist republic released the Muslim Chinese from oppression, and the Communist multiculturalism opened up the Sinophone cultural landscape to Hui and other 'ethnicities' or 'nationalities'. And, as I have already mentioned, it echoes the structures and narrative trajectories of Arabic and Persian devotional works.

Similar intertwined contradictory impulses drive the narrative in A Muslim Funeral. The desire for a singular Muslim identity goes hand in hand with the will to belong to China culturally. Huo turns to jade, the craft which her family mastered and relied on for its livelihood until her generation, and structures her story of a Muslim family fighting for survival in the twentieth century around the historical role of Chinese Muslims in jade trade and craft. ${ }^{29}$ Jade, in this novel, is the site of the convergence of the various strands of the history of the Hui. The history of Chinese Muslims is told 
through the story of jade as their contributions are integrated into the history of jade craft in China. Han Ziqi relates the lineage of his and his father-in-law's craft to famous Chinese masters in Chinese history. The last commission Liang Yiqin receives and accepts is transforming a large scroll depicting the famous Ming Muslim general Zheng He (1371-1433) commanding his large fleet in the south seas into a panel of jade carving. Such twining of Hui and Han destiny is even more evident in the twentieth century as China went through the turmoil of the republican upheaval, the Communist takeover and the Cultural Revolution, when very few were lucky enough to escape persecution and death. Practically all Chinese experienced the same vicissitudes in their fortunes as the Liang-Han family. Many had to give up their upper- or middle-class lifestyles, in fact, most of their worldly possessions, and live modestly and under surveillance, especially during the Cultural Revolution. Han has to move from his mansion and he even loses his priceless jade collection during a Red Guard raid of his house, a collection for which he suffered separation from his wife and young son when he took it to London for safekeeping during World War Two.

This shared history has not prevented Han exploitation of Hui. Pu Shochang (蒲壽昌), the Han jade trader and broker, who commissions the Zheng He jade carving on behalf of an English collector, Simon Hunt (沙蒙亨特), gives Liang a price drastically less than he had agreed with Hunt, advances a small portion of this amount to Liang, and when Liang's fall breaks the panel as he dies from exhaustion, has no scruples taking away the broken panel and collecting the entire fee from Hunt, and at the same time exacting compensation from the Liang family, indenturing Han to his service for three years. If Han had not met Hunt by accident at Pu's shop during his three-year indentured servitude after Liang's death he would not have found out how Pu had been taking advantage of Liang's honesty and timidity. Liang's habitual self-effacing modesty is in part a personality trait and in part a strategy of Hui survival in a sea of more numerous and powerful Han. It is his way of not attracting attention to his otherness and of keeping potential trouble at bay. Hard work, mastery of his craft, and faith in his God are his credo. In this he is not very different from other naïve protagonists in modern Chinese fiction, and the story of his exploitation by a wealthy broker is a familiar one; however, his self-conscious identification of himself as outsider and his reflexive instinct to avoid disagreement or strife and accept comewhat-may seem to gesture towards a strategy of survival learned through cumulative collective experience.

This subversive undercurrent in Huo's narrative brings the identity politics of her novel closer to those of Zhang's more vociferous contestation of Chinese historiography as the narrative of the victors that glorifies violent acts of suppression as legitimate battles in a just war. Both insist on the simultaneous insider/ outsider status of Hui in China. While they uncover the 'hidden history' of Hui in 
China and highlight the Hui contributions to Chinese culture, they also seek for their works a lineage in the classic Chinese novels. A History of the Soul evokes The Romance of the Three Kingdoms as a kindred historical novel, A Muslim Funeral is more akin to the 'erotic romances' that interrogate and bring into dialogue Buddhist, Confucian, and Daoist worldviews through the actions of private individuals and their relationships within the walls of a traditional Chinese mansion (si-he-yuan, 四合院), such as A Dream of Red Mansions ${ }^{30}$ (or Dream of the Red Chamber) ${ }^{31}$ and The Golden Lotus ${ }^{32}$ (or The Plum in the Golden Vase). ${ }^{33}$ Love and sex, also the subject of secret histories of the imperial palaces ( $m i$-shi, 密史), are the site of discourses on dominant ideologies, societal forces, and individual destinies. Whether in Zhang's alternative history of the Jahriyya or Huo's story of love and loss in the Liang/ Han household, family is at the heart of communal organisation and destiny. The two novels are in effect family sagas through which the history of a community is narrated. Family remains at the heart of any vision of community and construction of identity.

\section{Family Sagas and Secret Histories}

The founder of the Jahriyya in China, Ma Mingxin, gave explicit instructions to his followers not to follow the structures of other Sūfī menhuan in China. Those organised themselves around the family of their leaders, who inherited leadership (and sacred knowledge) son from the father, collected taxes and donations from their followers, and built up armies around themselves. Ma rather insisted on living an ascetic life, refusing donations from his followers, and passing on the leadership of the community to the most worthy. His followers would throw his edicts to the wind in a couple of generations, and by the time of Ma Hualong leadership would become hereditary and the leader some kind of 'warlord'. The story of the Jahriyya Zhang tells in A History of the Soul is indeed a family saga that, as I have already divulged, revolves around the Ma family and involves the search, protection and survival of Ma Mingxin's descendants. Bloodline is central not only to the survival of a community but also its legitimacy, especially that of their leadership. Zhang's novel gives coherence to the history of the Jahriyya in China by constructing, or reconstructing, the patrilineal genealogy of Ma family, and tracking the members dispersed in the various regions of China who met with violent death at the hands of Qing officials in order to bring them into focus under the Ma family tree. The Arabic and Persian 'secret histories' Zhang discovers provide the details for his portraits of these 'martyrs' of Jahriyya.

Huo writes a three-generation family saga centred on the love lives of Liang Yiqin's two daughters and their children. The arrival of an outsider, Han Ziqi, precipitates the tragedy that brings the story of Hui in a tumultuous China to an end as the Chinese say farewell to the Cultural Revolution. Han, the disciple of Liang, is like a son to him. 
He fulfills his duties as both disciple and son when he indentures himself to $\mathrm{Pu}$ in order to save his master's wife and two daughters. As soon as the contract comes to an end, he returns to the Liang family, marries Liang Yiqin's elder daughter, Junbi, and together they rebuild the Liang business. He even buys a traditional Chinese mansion and moves the family there. He soon has a son, Tianxing, and his business prospers. In time he becomes a famous collector of antique Chinese jade artifacts. World War Two unleashes fear in Junbi's sister, Biyu, who longs to go to Europe and escape the turbulent events in China. Han, eager to take his jade collection to safety, accepts Hunt's invitation and takes Biyu to London. There, Biyu falls in love with Simon Hunt's son, Oliver, who, alas, dies violently in a German bombing. When the Hunt family removes to the countryside, Han and Biyu stay behind and in time they fall in love and have a daughter, Xinyue. They return to Beijing after the war, only for Biyu to return to England in the face of her sister's wrath, leaving her daughter behind. An 'adopted' aunt, a Hui woman whom the Han family took in at the time Tianxing was born, raises Xinyue. This set of intertwined sexual relationships inside the Liang family is only revealed at the end of the novel.

The novel, instead, begins in suspense. A shadowy woman arrives at the former Han residence only to find that it has been transformed into a historical building now owned by the government. This is followed by a quick episode recounting Han's purchase of the mansion. The story proper opens with Han's younger daughter, Xinyue, returning home after her University entrance exam, to face a hostile reaction from her 'mother'. But of course she does not know and will never know that the woman she knows as her mother is in fact her aunt. For Huo keeps us in suspense, without giving away the secret behind the tension in the family, and wraps the four love stories of the two generations around each other until the very last moment, when the narrative returns to the shadowy figure of a woman, only for her to learn of the deaths of her lover and daughter. Secrecy is the key ingredient in the story Huo tells. The stories of star-crossed lovers mirror the tumult of the age they live in and, more importantly, expose a secret history that can unravel the delicate fabric of Hui identity constructed as and through family sagas such as A Muslim Funeral and A History of the Soul. The inward looking community, represented by the extremity of Junbi's position, who insists that Muslims can marry only Muslims, is undermined by her sister, who seems to take this edict to the extreme and engages with a love affair with her brother-in-law, and is unraveled by the confession Han makes on his deathbed: he is in fact Han not Hui. What kind of funeral should she give Han Ziqi? The question comes to Junbi's mind immediately, as she becomes anxious over Tianxing and Xinyue's mixed blood. Han's confession makes a mockery of Junbi's meticulous life-long observance of strict Islamic edicts in order to maintain the 'purity' or 'authenticity' of her family's Hui lineage. Nothing, however, has protected her or her family from Han 'contamination'. In the end, even 'inbreeding', that the two sisters 
should have children with the same man, has not guaranteed the purity of Liang family's Hui bloodline.

Love and sex in A Muslim Funeral are the means through which various forms of intercourse between Hui and Han are interrogated and negotiated. The walls of the mansion may keep the outside world at bay, and the strict observance of Islamic edicts may prevent the outsider from 'polluting' the Hui blood, but the Hui are helpless in the face of what day-to-day interaction among people can bring. The Hui, in order to survive and prosper in China, cannot live in isolation, and as soon as they leave the inner sanctums of their 'mansions', physically or figuratively, they will encounter challenges and seductions. Liang Yiqin and Han Ziqi must resist the allure of Han culture, but while Liang succeeds in maintaining his aloofness, Han joins the long line of Han collectors of jade (though he is Han). Both Han Tianxing and Han Xinyue fall in love with Han, rather than Hui. Tianxing's marriage and Xinyue's death are illusory victories for Liang Junbi, for, as she discovers, her children are of mixed Hui and Han blood. The walls of the mansion are unable to block the entry of a pretender like Han Ziqi, and Junbi's rules cannot prevent 'her' children from falling in love with the 'wrong' people. There is nothing sinister in Han's deceit, for he was a poor orphan desperate to find a home, or in Tianxing and Xinyue's love, for it is the natural outcome of congenial social intercourse - the objects of their love are indeed good people.

\section{Identity, Anxiety of Belonging and the Qur'an}

The family saga at the heart of A History of the Soul and A Muslim Funeral is the site on which the anxiety of belonging is grappled with and expressed. The willed coherence of Ma family genealogy in the former and the inadvertent unraveling of the Liang/Han family bloodline in the latter are two faces of the same anxiety of belonging. They are expressive of the same lack of coherence in Hui identity. Hui, as scholars of Islam in China have all pointed out, is an elusive conceptual category that finds no corroboration in notions of 'ethnicity' or 'nationality' widely used in relation to multiculturalism in China. Hui identity is based more on religion than either 'ethnicity' or 'nationality'. Perhaps more importantly, however, is the realisation by Zhang and Huo that identity is viable only as a construct, as an effect of narrative and discourse. Zhang's construction of the genealogy of the Ma family and Huo's deconstruction of the bloodline of the Liang/Han family both point to the impossibility of certainty in tracing Hui to any ancestry let alone any 'ethnicity' or 'nationality'. After all, a last name like Ma for a Hui, to take one example, may be a phonetic transcription of any Muslim proper name that begins with an ' $m$ ' sound, such as Muhammad. This 'm' may equally be transcribed as Mu. Hui last names, unlike those of Han, do not necessarily refer to lineage. Moreover, even lineage among Han is more often than not subject to adoption and fabrication. 
God's edict in Hold fast to God's rope all together (Q. 3:103) finds new resonances in the Chinese context. The Chinese Muslims have indeed divided into factions often engaged in internal fighting, and the instruction contained in 'do not split into factions' has not been obeyed. In the face of this disunity, what, then, are Hui to do when their integration into the local population has erased even their 'original' distinct physical features, not to mention cultural practices, and their distance from their 'original' homeland has removed them from a 'majority' status and interrupted their access to their sacred text and a live interpretive community? Hold fast to God's rope all together becomes a message about faith as spirituality in Zhang's novel and religious rituals as a way of defining and preserving 'minority' community in Huo's. The Qur'an, which for an Arabic reader is an experience of the word in its language world, and a paradigmatic text that gives shape to worldview, knowledge, and narrative that inhere in Arabic texts, is experienced secondhand and as paratext not text. There are numerous references to the Qur'an in A Muslim Funeral, but these are all paraphrases that begin with 'The Qur'an instructs' and end in summation not quotation. These frequent mentions of the Qur'an in Huo's novel cannot fill the lacunae left gaping by its conspicuous absence as a paradigmatic text that lives in and defines a language world, as one finds in Arabic writings. Both Zhang and Huo evoke the spiritual and moral authority of the Qur'an but they do not and, most likely cannot, impart or manifest its literary presence, as one can in Arabic texts. The Qur'an is a 'foreign' element in the Sinophone world in which their texts are enmeshed. The aesthetics of their works, despite Zhang's borrowings from various genres of Arabic and Persian Șūfī expressions and Huo's elaborate explication of Muslim rituals, is derived from Chinese poetics, and the structures of their narratives come from from the classic Chinese novel. The Qur' an may be absent as a text but its presence in the mind and heart of the Muslim Chinese is not in doubt. That they have no direct access to it has also given them the impetus to look elsewhere for distinguishing identity markers. These markers, if Zhang's 'fundamentalism' may be contrasted to Huo's 'scepticism', are necessarily diverse and divergent, just like the Muslims in China.

\section{NOTES}

1 Note on transliteration of Chinese characters: the Pinyin system of transliteration is followed except for key Chinese transliteration of Arabic and Persian terms. I use a hyphen to separate the Chinese characters so that readers unfamiliar with Chinese will be able to follow the discussion of Zhang and Huo's language games.

2 Zhang and Huo are the two most important Muslim Chinese writers singled out for study in the works of Hui critic, Ma Lirong. Her numerous essays on Zhang and Huo are integrated into a book under the title of '20 世紀中國文學與伊斯蘭文化', or Twentieth Century Chinese Literature and Islamic Culture (my translation).

3 Pillsbury, 'Muslim History in China', vol. 1, p. 121.

4 Gillette, Between Mecca and Beijing, p. 102. 
5 Gillette, Between Mecca and Beijing, pp. 103-8.

6 Gillette, Between Mecca and Beijing, pp. 108-11.

7 See Zang, Ethnicity and Urban Life in China.

8 Both 'ethnicity' and 'nationality' have been used as translations of the Chinese term 民族 (minzu). Equivalence is illusive, and the application of the concepts of 'ethnicity' or 'nationality' to the Chinese context is problematic. On the problematic conceptual issues relevant to peoples of China, see Lipman, Familiar Strangers. See also Dikötter, The Construction of Racial Identities; Gladney, Muslim Chinese; Gladney, Ethnic Identity in China; Gladney, Dislocating China; Israeli, Muslims in China; Israeli, Islam in China; Dillon, China's Muslims; Dillon, China's Muslim Hui Community; and Leslie, The Integration of Religious Minorities in China.

9 Mao Dun (1896-1981) was the pen name of Shen Dehong, a prominent twentieth-century Chinese novelist, cultural critic, and journalist. He was also the Minister of Culture of China from 1949 to 1965. The Mao Dun Literature Prize (茅盾文学奖), established in the will of Mao Dun (for which he personally donated 250,000 RMB) and sponsored by the Chinese Writers Association, first bestowed in 1982, is awarded every four years to a novel; it is one of the most prestigious literature prizes in China. A Muslim Funeral has been translated into Arabic, Bengali, English, French, and Urdu; however, I have only been able to locate the English translation by Guan Yuehua, as Jade King: History of a Chinese Muslim Family.

10 For a survey of literary movements and works of this period, see Zicheng, A History of Contemporary Chinese Literature. For the ways in which Zhang's works may be related to the movements of this period, see also Choy, Remapping the Past, 'Introduction', pp. 1-15, and 'The Outlying and the Peripheral: Myths of Migrants and Minorities', pp. 79-102.

11 See Deleuze and Guattari, Kafka.

12 There is a growing body of scholarship on Islam and Muslims in China. The two-volume Islam in China: Key Papers, edited by Michael Dillon, provides a glimpse of the main directions and major authors of this scholarship. On the more specific contributions of Muslim scholars to Islam in China and Chinese culture and literature in the seventeenth and eighteenth centuries, see Benite, The Dao of Muhammad. See also note 8 above. For works in Chinese, see 清代代中國伊斯蘭教論; 回族民間文學史綱, 寧夏大學司族文學研究所; 中國回族史; and 中國少數民族文學.

13 Wang has compiled a very useful trilingual Glossary of Chinese Islamic Terms that provides a three-way translation of these Arabic and Persian words.

14 The Jahriyya is a branch of the Naqshabandiyya Sunfĩ order. For the spread of the Naqshabandiyya in China, see Fletcher, Studies on Chinese and Islamic Inner Asia. See also 中 國伊斯蘭教派門宦溯源.

15 張, 心靈史, p. 4.

16 This idealism based on spirituality in A History of the Soul is the feature in Zhang's writing that has attracted the most critical attention. See Xuelian, 'Muslim Identity'; Xu, 'Radical Ethnicity and Apocryphal History'; Choy, 'The Outlying and the Peripheral' in Remapping the Past, pp. 65-132; Henning, 'History of the Soul'; and Jin, 'A New Politics of Faith'.

17 張, 心靈史, p. 9.

18 Rossabi, Governing China's Multiethnic Frontiers, 'Introduction', p. 9.

19 For his role in Qing suppression of the Muslims, see Fields, Tso Tsung-t'ang and the Muslims.

20 References are made to 霍穆斯林的葬禮, vol. 1, p. 15.

21 霍 穆斯林的葬禮, vol. 1, p. 32. 
22 霍 穆斯林的葬禮, vol. 1, p. 38 .

23 霍穆斯林的葬禮, vol. 1, pp. 141-5.

24 霍穆斯林的葬禮, vol. 1, pp. 244-5.

25 Choy, Remapping the Past, pp. 85-8.

26 For further details, see Choy, Remapping the Past, pp. 89-102.

27 For a discussion of the Hui insurrections in the eighteenth and nineteenth centuries and the ways in which these colluded with other insurrections, see Lipman, Familiar Strangers, and ch. 5 'Hui Insurrections in the Nineteenth Century' in Dillon, China's Muslim Hui Community, pp. 57-74. For a comprehensive reading list of works in English on the Hui insurrections in northwest China and the Qing policies of suppression, see the bibliography in Lipman, Familiar Strangers.

28 English translation by Roberts, Three Kingdoms, p. 5.

29 'For example, Hui families all over China have taken up transporting, carving, and selling jade as their specialty. Even in Beijing and Shanghai, some of the most famous and prosperous jade dealers are Hui. They have undertaken this work in part because the most important domestic source for jade within the PRC (and within the Qing empire in centuries past) lies in Xinjiang, China's huge northwesternmost province, whose population was until the midtwentieth century overwhelmingly Turkic and Muslim' (Lipman, 'White Hats, Oil Cakes, and Common Blood', p. 32).

30 This reference is to the 1978-80 translation of Cao Xueqin's Hong lou meng by Yang Hsien-yi and Gladys Yang.

31 This appears in the title of David Hawkes's translation, The Story of Stone, also known as The Dream of the Red Chamber, in five volumes, published between 1973 and 1986.

32 The title of the 1939 English translation of Jin ping mei by Xiaoxiaosheng in four volumes by Clement Egerton.

33 This is the title of the more recent English translation (published between 1993 and 2013) by David Tod Roy.

\section{Bibliography}

Ahmed, Leila, Women and Gender in Islam: Historical Roots of a Modern Debate (New Haven: Yale University Press, 1992).

Benite, Zvi Ben-Dor, The Dao of Muhammad: A Cultural History of Muslims in Late Imperial China (Cambridge, MA: Harvard University East Asia Center, 2005).

Cao, Xueqin, A Dream of Red Mansions, tr. Yang Hsien-yi and Gladys Yang (Beijing: Foreign Language Press, 1978-80).

- The Story of the Stone, also Known as the Dream of the Red Chamber, tr. David Hawkes (Harmondsworth and New York: Penguin Books, 1973-86).

Choy, Howard Y.F., Remapping the Past: Fictions of History in Deng's China, 1979-1997 (Leiden and Boston: Brill 2008).

Ciu, Shusen [邱树森] (ed.), Zhongguo huizu shi [中国回族史] (2 vols, Ningxia: Ningxia renmin chubanshe [宁夏人民出版社], 1996).

Deleuze, Gilles and Félix Guattari, Kafka: Toward a Minor Literature, tr. Dana Polan (Minneapolis and London: University of Minnesota Press, 1986). 
Dikötter, Frank (ed.), The Construction of Racial Identities in China and Japan: Historical and Contemporary Perspectives (London: Hurst \& Company, 1997).

Dillon, Michael (ed.), Islam in China: Key Papers in Two Volumes (Folkestone, Kent: Global Oriental, 2009).

_- China's Muslims (Hong Kong and New York: Oxford University Press, 1996).

—, China's Muslim Hui Community: Migration, Settlement and Sects (Richmond, Surrey: Curzon, 1999).

Fields, Lanny B., Tso Tsung-t'ang and the Muslims: Statecraft in Northwest China 1868-1880 (Kingston, Ont.: Limestone Press, 1978).

Fletcher, Joseph, Studies on Chinese and Islamic Inner Asia, ed. Beatrice Manz (London: Variorum, 1995).

Gillette, Maris Boyd, Between Mecca and Beijing: Modernization and Consumption Among Urban Chinese Muslims (Stanford, CA: Stanford University Press, 2000).

Gladney, Dru C., Muslim Chinese: Ethnic Nationalism in the People's Republic (Cambridge, MA: Harvard University Press, 1991).

_ Ethnic Identity in China: the Making of a Muslim Minority Nationality (Fort Worth, TX: Harcourt Brace College Publishers, 1998).

_, Dislocating China: Muslims, Minorities and other Subaltern Subjects (Chicago and London: University of Chicago Press, 2004).

Henning, Stefan, 'History of the Soul: A Chinese Writer, Nietzsche, and Tiananmen 1989', Comparative Studies in History and Society 51:3 (2009), pp. 473-501.

Hong, Zicheng, A History of Contemporary Chinese Literature, tr. Michael M. Day (Leiden, Boston: Brill, 2007).

Huo, Da [霍達], Musilin de zanglin [穆斯林的葬禮] (2 vols, Taipei: Guojicun wenku shudian [臺北: 國際村文庫書店], 1993); English translation by Guan Yuehua, Jade King: History of a Chinese Muslim Family (Beijing: Panda Books, 1992).

Israeli, Raphael, Muslims in China: A Study in Cultural Confrontation (London: Curzon, 1978).

_- Islam in China: A Critical Bibliography (Westport, CT: Greenwood Press, 1994).

Jin, Wen, 'A New Politics of Faith: Zhang Chengzhi's Xinling shi and Rabih Alameddine's Koolaids: The Art of War' in Wen Jin, Pluralist Universalism: An Asian American Critique of US and Chinese Multiculturalism (Columbus: The Ohio State University Press, 2012), pp. 137-72.

Leslie, Donald, The Integration of Religious Minorities in China: the Case of Chinese Muslims (Canberra: Australian National University, 1998).

Lipman, Jonathan N., 'White Hats, Oil Cakes, and Common Blood: The Hui in the Contemporary Chinese State' in Morris Rossabi (ed.), Governing China's Multiethnic Frontiers (Seattle and London: University of Washington Press, 2004), pp. 19-52. 
_- Familiar Strangers: A History of Muslims in Northwest China (Seattle and London: University of Washington Press, 1997).

Ma, Lirong[马丽容], Ershi shiji Zhongguo wenxue yu Yisilan wenhua [20 世纪中国 文学与伊斯兰文化] (Hefei: Anhui jiaoyu chubanshe [合肥: 安徽教育出版社], 2000).

Ma, Tong[马通], Zhongguo Yisilan jiaopai menhuan suoyuan [中国伊斯兰教派门宦 溯源] (Ningxia: Ningxia renmin chubanshe [寧夏人民出版社], 1978).

Mao, Xing [毛星], Zhongguo shaoshu minzu wenxue [中国少数民族文学] (Hunan: Hunan renmin chubanshe [湖南人民出版社], 1983).

Pillsbury, Barbara L.K., 'Muslim History in China: A 1300-Year Chronology' in Michael Dillon (ed.), Islam in China: Key Papers (Folkestone, Kent: Global Oriental, 2009), vol. 1, pp. 109-27.

一, [宁夏哲学社会科学研究所], Qingdai Zhongguo Yisilan jiaolun ji [清代中国 伊斯兰教论集] (Ningxia: Ningxia renmin chubanshe [宁夏: 人民出阪社], 1981).

Roberts, Moss, Three Kingdoms: A Historical Novel, attributed to Luo Guangzhong (Berkeley, Los Angeles, Oxford and Beijing: University of California Press and Foreign Languages Press, 1991).

Rossabi, Morris, Governing China's Multiethnic Frontiers (Seattle and London: University of Washington Press, 2004).

Shujiang, Li [李树江], Huizu minjian wenxue shigan [回族民间文学史纲] (Ningxia: Ningxia renmin chubanshe [宁夏人民出版社], 1989).

Wang, Jianping, Glossary of Chinese Islamic Terms (Richmond, Surrey: Curzon Press, 2001).

Xiaoxiaosheng, The Plum in the Golden Vase, tr. David Tod Roy (5 vols. Princeton: Princeton University Press, 1993-2013).

—, The Golden Lotus, tr. Clement Egerton (4 vols, n.p.,1939).

$\mathrm{Xu}$, Jian, 'Radical Ethnicity and Apocryphal History: Reading the Sublime Object of Humanism in Zhang Chengzhi's Late Fictions', Positions: East Asia Cultures Critique 10:3 (2002), pp. 525-46.

Zhang, Chengzhi [张承志], Xinling shi [心灵史] (Hunan: Hunan wenxue chubanshe [湖南文学出版社], 1991).

Zang, Xiaowei, Ethnicity and Urban Life in China: a Comparative Study of Hui Muslims and Han Chinese (London and New York: Routledge, 2007).

Zhang, Xuelian, 'Muslim Identity in the Writings of Zhang Chengzhi', Journal of the Oriental Society of Australia 32-3 (2000-1), pp. 97-116. 